\title{
An Analysis on Commissive Utterances in The Film Entitled "The Gods Must Be Crazy" and Its Implication on Teaching Speaking
}

\author{
Rizqi Arum Prastuti, Suparno, and Kristiandi
}

\author{
English Education Department \\ Teacher Training and Education Faculty \\ Sebelas Maret University of Surakarta
}

Email: arumprastuti@gmail.com

\begin{abstract}
The aims of this study were to find out 1) the types of commissive utterances; 2) the strategy in employing commissive utterances in the film entitled "The God Must be Crazy"; and 3) its context of situation. This study uses descriptive qualitative method. In collecting the data, the writer used the film entitled "The Gods Must be Crazy" and its transcript as the source of the data. The findings of this study are 1) the types of commissive utterances that found in the film are promise, refusal, threat, and offer; 2) in general, the characters of the film mostly use indirect speech act, they mostly use explanation, excuse or reason in employing refusals, use If-then in employing threat, use interrogative with modal and justification in employing offers; 3 ) the way of the characters in the film entitled "The Gods Must be Crazy" in choosing the strategy of employing the utterances are influenced by the factors like social status of the interlocutors, the relationship between the participants, and the situation when the conversation occurs.
\end{abstract}

Keywords: pragmatic, speech act, commissive

\section{INTRODUCTION}

People are surrounded by others, trying to understand the others and they want the other understand them (Adler \& Rodman, 2006: 9). They fulfill their want by communicating. In communicating with others, people share their ideas, thought, information, feeling, etc. They express their ideas, feeling, or thoughts through utterances. Various ideas, thoughts, wants, and feelings that people want to say to others make them produce utterances. The utterances produced at home will be different from the utterances produced in a business meeting or in a birthday party. The utterances produced when talking to the boss or workers, wife or husband, friends, a customer or a shopkeeper are also different.

Utterances produced by people are not the same because of the context in which the conversation occurs. Holmes (1992: 282) states that what people say reflects the context in which they are using the language. The situation where the conversation occurs, to whom people are talking to, the purpose of the speakers want to reach, and the social distance between the participants do influence the way people talk (p. 11). The same two participants may use different utterances where the situation of their conversation occurs are different. The same two participants, when they are in meeting and in birthday party, they will use different 
utterances when they speak. Moreover, one may use different utterances towards different people too. The way how one talks to his parents will be different with the way of his talking to his boss.

"A communicative view of language holds as axiomatic that when people say something, they are also doing something" (Thornbury, 2005: 16). It means that when people say something, they do not only produce utterances, but also do some actions. Through those utterances, people want the hearer to do something towards their saying. Those actions performed through utterance are called speech acts (Yule, 1996: 47). According to Austin (in Allan, 1986: 164), every utterance produced by speaker performs an act such as stating a fact or opinion, confirming or denying something, making a prediction or a request, asking a question, issuing an order, giving advice or permission, making an offer or a promise, greeting, thanking, condoling, effecting a baptism, or declaring an umpire ${ }^{e e} s$ decision, and so forth.

In daily conversation, people sometimes commit themselves to some future actions. When people want to commit themselves in some future actions, they use commissive utterances. Commissives, based on Searle (1979: 14), are speech acts whose speakers use to commit themselves to do some future actions. This kind of speech acts is aimed to express what the speakers intend. They are promise, refuse, threat, and offer. When people use commissive utterances, they make the world agree the words. Commissives can be performed by the speaker alone, or as a member of group (Yule, 1996: 54).

Commissive utterances can be found in the film, beside in the real life.
Film is the reflection of social life since it represents the norms, values, and phenomena of the society and also reflects the desires, needs, fears, and aspirations of a society. It means that everything in film can be said as the phenomenon of real life including the conversation. The conversation occurs in the real life is closely the same with the conversation occurs in the film since what happens in the film is based on the real life. There are many utterances uttered in the film, including commissive utterances.

In "The Gods Must be Crazy", there are various types of commissive utterances produced by the characters of the film. The various types of commissive utterances are influenced by certain social and situational context presented in the film. For example, when one of the characters was asked to do something, he refused it by using excuses without the word „no ${ }^{\text {ee }}$ since the one who asked him was someone in a higher position. In contrast, he used criticism in refusing someone ${ }^{e e}$ advice, which was his friend.

The aims of the study are 1) to find out the types of commissive utterances employed by the characters in the film entitled "The God Must be Crazy", 2) to describe how the characters employ the strategy in uttering commissive utterances, and 3) to describe the context of situation in which each commissive utterances is employed by the characters of the film entitled "The God Must be Crazy".

\section{RESEARCH METHODS}

The writer used descriptive qualitative method to describe the phenomena of commissive utterances in the film entitled "The Gods Must be Crazy". This research used purposive sampling technique. The writer only used 
the data by selecting them so that this kind of sampling would ease in analyzing the data related to the field of study. Based on some criteria of the data, the data used in this research were the selected-data

containing commissive utterances, especially commissive utterances uttered by non native speakers of English characters.

To collect the data, the writer used the film "The Gods Must be Crazy" and its script. The dialogue script of the film "The Gods Must be Crazy" was compared with the video of the film "The Gods Must be Crazy". Then, the writer took note on all of the dialogs containing commissives utterances as the data of the research. After the data were gathered, the writer analyzed them by following some stages which were identifying the type of commissive utterances, describing the context, and describing the strategy used by the characters of the film "The Gods Must be Crazy" in employing commissive utterances. In identifying the type of commissive utterances, the writer used
Searle $\mathrm{s}$ theory of Speech Acts. In describing the context, the writer used Ethnography of Communication with SPEAKING formula as the guideline. In describing the strategy used by the characters of the film "The Gods Must be Crazy" in employing the commissive utterances, the writer used some theories like Beebe et al. and Charteres s theory.

\section{RESEARCH FINDINGS DISCUSSION FINDINGS}

The types of commissive utterances employed by the characters in the film entitled "The Gods Must be Crazy" can be identified based on the Searle $s$ speech acts classification namely promise, refusal, threat, and offer. Based the data analysis, it can be concluded that all of the types mentioned before are found in the film. The researcher found that there are 2 data of promise, 12 data of refusals, 1 datum of threat, and 2 data of offers. Those can be presented on the table 1 .

Table 1. Types of Commissive

\begin{tabular}{llll}
\hline No & Type of Commissive & $\Sigma$ Data & Percentage \\
\hline 1 & Promise & 2 & $11.76 \%$ \\
2 & Refusal & 12 & $70.59 \%$ \\
3 & Threat & 1 & $5.89 \%$ \\
4 & Offer & 2 & $11.76 \%$ \\
& Total & 17 & $100 \%$ \\
\hline
\end{tabular}

Table 2. Basic Types of Speech Acts in Employing Commissive Utterance

\begin{tabular}{llll}
\hline No & Basic Types of Speech Acts & $\Sigma$ Data & Percentage \\
\hline 1 & Direct & 2 & $11.76 \%$ \\
2 & Indirect & 15 & $88.24 \%$ \\
& Total & 17 & $100 \%$ \\
\hline
\end{tabular}

Table 3. Refusal Strategies

\begin{tabular}{llll}
\hline No & Strategy & $\Sigma$ Data & Percentage \\
\hline 1 & Non performative statement "No" & 1 & $8.33 \%$ \\
2 & Non performative statement (negative willingness) & 1 & $8.33 \%$ \\
3 & Explanation, reason, excuse & 5 & $41.67 \%$
\end{tabular}




\begin{tabular}{llll}
4 & Statement of alternative & 1 & $8.33 \%$ \\
5 & Set conditions for future acceptance & 2 & $16.67 \%$ \\
6 & Attempt to dissuade interlocutor (Statement of negative) & 1 & $8.33 \%$ \\
7 & Attempt to dissuade interlocutor (Self defense) & 1 & $8.33 \%$ \\
& Total & 12 & $100 \%$ \\
\hline
\end{tabular}

Table 4. Threat Strategies

\begin{tabular}{llll}
\hline No & Strategy & $\Sigma$ Data & Percentage \\
\hline 1 & If-then & 1 & $100 \%$ \\
& Total & 1 & $100 \%$ \\
\hline
\end{tabular}

Table 5. Offer Strategies

\begin{tabular}{llll}
\hline No & Strategy & $\Sigma$ Data & Percentage \\
\hline 1 & Interrogative using modal & 1 & $50 \%$ \\
2 & Justifications & 1 & $50 \%$ \\
& Total & 2 & $100 \%$ \\
\hline
\end{tabular}

\section{DISCUSSION}

The characters in the film entitled "The Gods Must be Crazy" mostly use refusal in employing commissive utterances. Refusals employed by the characters in the film can be found in data number 02, 03, 04, 07, 08, 09, 10, 11, 12, 14, 15, and 16. Those refusals are employed when the characters in the film try to refuse interlocutors ${ }^{\text {ee }}$ ask, request, apologize, and advice. Most of the refusals are employed by Mpudi. Data number 02, 03, and 04 show that Mpudi refuses indirectly the request of the interlocutors, the Reverend and Steyn, to repair the car. In datum number 07, Mpudi indirectly refuses Steyn ees advice not to do anything silly. The other data that show Mpudi employs refusals are data number 09, 15,

16. In datum number 09, Mpudi refuses directly Jack ${ }^{e e}$ s apology. Data number 15 and 16 show that Mpudi refuses Steyn"s order to get some rope. In datum number

15, Mpudi refuses Steyn 'es order directly. In contrast, datum number 16 shows that he employs refusal indirectly.

The findings show that there are two data of promise. In this film, promises are employed by the characters to show that they want to do something in the future. Datum number 05 shows that the speaker, Mpudi, commits himself to repair the car, after being pushed by the Reverend and Steyn. He commits himself to repair the car indirectly by saying that the car will be able to be used after he repairs it. In datum number 06, Mpudi employs promise to show his willingness to get $\mathrm{Xi}$ out from the jail. He shows his willingness by stating that he wants to do something to $\mathrm{Xi}$.

Not only promise, but also offer that identified has two data. Those are data number 01 and 17. Datum number 01 shows that the character, Pete, employs offer indirectly to Kate about the idea of teacher shortage in Bostwana. He asks first whether Kate uses his idea or not. In contrast, in datum number 17, Mpudi employs offer indirectly. He judges that his friend, Steyn, is in trouble so he decides himself to accompany him to meet Kate. Mpudi offers a help without asking Steyn first.

Based on the findings of the research, the characters in the film entitled 
"The Gods Must be Crazy" mostly employ commissive utterances indirectly. Form 17 data that had been analyzed, there are 15 data that classified as indirect speech acts, and the rest are direct speech acts. The situation when the conversation occurs makes the characters in the film employ commissive utterances directly. In datum number 09, the character, Mpudi, employs commissive utterance directly because has disadvantage of it. The situation is so embarrassing for the speaker, Mpudi. He seems angry to Jack because he lets him alone chased by the lion. So when Jack apologizes, he refuses it directly.

According to the findings, refusals strategy that mostly used by the characters in the film is explanation, reason, excuse. This strategy is found in data number 02 , 04, 07, 08, and 11. The characters use explanation, reason, excuse in employing refusal in order to avoid interlocutors "e ask, request, order, and advice. In data number 02 and 04, the character, Mpudi, tries to avoid interlocutors ${ }^{\text {ee }}$ order to repair the car. In datum number 07, Mpudi employs reason to refuse advice of his friend, Steyn. Datum number 08 shows that the officer uses explanation in employing refusal. He explains to Steyn that Xi needs 11 weeks to go because previously Steyn asks him to let $\mathrm{Xi}$ go from the jail. In datum number 11, Sam Boga refuses by giving excuse to Kate ${ }^{\text {ee }}$ s request. Kate still requests to let the hostages rest, but Sam Boga keeps refusing it by giving excuse that it is still long way to Motambe, so they should keep going.

From 17 utterances that had been analyzed, threat is only found 1 datum. Datum number 13 is classified as a threat. Threat is employed by Sam Boga, an antagonist character in the film. He employs threat because he feels annoyed by Kate, the person who keeps requesting him to let the hostages go. Because he is an abductor in that situation, he has the advantage to threaten all of the hostages.

Based on the findings, there are two data of offer. The characters use interrogative using modal and justification to offer their help. In datum number 01, the character, Pete, employs offer by using interrogative using modal. $\mathrm{He}$ wants to help Kate, his colleague, after she gets bawled by her boss by offering the idea about teacher shortage in Bostwana. Another offer in datum number 17, the character, Mpudi, offers without asking permission to Steyn. He just says that Steyn needs some moral support, and he runs to him. He uses justification in employing offer, judging that Steyn needs some moral support, looking from his attitude, sign that he is so nervous. He offers it without asking permission to Steyn.

There are also some the strategies that the characters especially non native speakers of English in the film entitled "The Gods Must be Crazy" employed in uttering promise. In uttering promise, the characters in the film use modal, ,willee and some words showing future action such as „want ${ }^{\text {ee }}$ and ,,as soon as ${ }^{\text {ee }}$. Modal, ,willee that the character used can be found in datum number 05 . In datum number 05 the word ,as soon as ${ }^{\text {ee }}$ is also found. Another word „want ${ }^{\text {ee }}$ is found in datum number 07.

According to the findings of the research, the utterances that are uttered by the characters in the film entitled "The Gods Must be Crazy", especially non native characters, are influenced by the context. The context surrounding the conversation makes some consideration of the speaker in uttering commissive utterances. As stated by Holmes, the 
situation where the conversation occurs, to whom people are talking to, the purpose of the speakers want to reach, and the social distance between the participants influence the way people talk.

The interlocutors influence the way people talking. From the finding of the research, some data show that the social status of the interlocutor influences the way people talk. For example, data number 02, 03, and 04. The interlocutor has the higher social status than the speaker. The interlocutor is the reverend, so in that conversation, he uses indirect refusal considering that they are in different social status. The speaker, Mpudi, does not want to hurt or threaten interlocutor ${ }^{\text {ee }}$ s face by refusing the request directly. So he uses indirect refusal instead of direct refusal. In contrast, data number 09 and 15 show direct refusal uttered by the speaker. The social status of the participants also influence there. The equal social status of the participants makes the speaker chooses direct refusal instead of the indirect one.

The relationship between the participants also influence the way people talk. Take data number 02 and 05 as the examples. The speaker, Mpudi, chooses the word „bastard ${ }^{\text {ee }}$ in talking to reverend. His choice of word indicates that his relationship with the reverend is intimate and friendly, rather than formal and distant. It means that he felt comfort to say such kind of word to reverend. The other examples are data number 09 and 15. The speaker, Mpudi again, uses direct refusal in refusing interlocutors ${ }^{\text {ee }}$ request and apologies. The consideration why he uses direct refusal is the relationship between them. The intimate relationship that they have makes Mpudi chooses the direct refusal in refusing their request and apologies. Datum number 08 shows indirect expressions uttered by the speaker. The speaker, the officer, has distant relationship with the interlocutor, Steyn, so he chooses indirect expression to convey what he means.

Another factor that influence the way people talk is the situation when the conversation occurs. Data number 08, 09, $10,11,12,13$, and 14 are the examples. In those data, the speaker, the officer (datum number 08) and also Sam Boga (data number $10,11,12,13$, and 14) have the advantage of the situation of the conversation. In data number 08,09 , and 10, the officer has the advantage, that he has authority compared to the interlocutor, Steyn. Since he has the authority, he uses indirect refusal to refuse Steyn ${ }^{\text {ee }}$ request. He feels that he has advantageous position so that he does not need to use direct refusal. In line with the officer, Sam Boga also has the advantage in the situation of the conversation. In data number 10,11 , 12, 13, and 14, Sam Bogaees position is the abductor who has gun and can use violence towards the hostages. In that situation, he feels the hostages have no guts against him so he replies Kate ${ }^{\text {ee }}$ request calmly and indirectly. Unfortunately, Kate has guts to keep requesting him. So, with that condition, Sam Boga threatens her. Not only her, but all of the hostages are threatened. Another example is datum number 09 . The situation when the conversation occurs is the situation where the speaker has disadvantage of it. The situation is so embarrassing for the speaker, Mpudi. He seems angry to Jack because he lets him alone chased by the lion. So when Jack apologizes, he refuses it directly.

Based on the conversation occurs in the film, the non native characters in the film entitled "The Gods Must be Crazy" 
can employ commissive utterances well. When they start the conversation or when

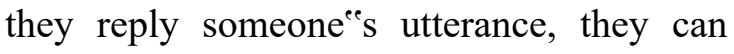
manage it well. Of course, not all of the conversations go as they expected. There are some utterances that unsuccessfully accepted by the interlocutors, who are native speakers of English. It does not mean that they can not employ commissive utterances well, but it is natural that not all the interlocutors ${ }^{\text {ee }}$ reply is in line with the speaker wants. In the conversation, the non native speaker characters in the film know how to utter commissive utterance, like in data number $01,06,07,13$, and 17, they know the situation of the conversation and the interlocutors who are native speakers of English, so they can employ the commissive utterances well. Moreover, they also can reply what non native speakers of English convey by using commissive utterances. They can interpret what lies behind the utterances of the interlocutors who are non native speakers. Because they can interpret it, so they also can reply it well using commissive utterances.

\section{CONCLUSIONS AND SUGGESTIONS}

Based on the findings and discussions, the writer makes some conclusions of this research. First, there are four types of commissive utterances employed by the characters of the film entitled "The Gods Must be Crazy". They are promise, refusal, threat, and offer.

There are two basic types of speech acts that are used by the characters in the film, namely direct and indirect speech acts. The

most speech acts that is used by the characters of the film is indirect speech acts $(88.24 \%)$.

Second, it is about the strategies. In employing refusals, the characters of the film mostly use explanation, excuse or reason $(41.67 \%)$. In employing threat, the strategy that is used by the characters of the film is only If-then (100\%). The strategies that are used by the characters of the film in employing offer are interrogative using modal $(50 \%)$ and justification $(50 \%)$. In uttering promise, the characters in the film use modal ,willee and some words showing future action such as ,"want ${ }^{\text {ee }}$ and ,,as soon as ${ }^{\text {ee }}$.

Third, the strategies that are used by the characters of the film are influenced by the context of the conversation. The factors like social status of the interlocutors, the relationship between the participants, and the situation when the conversation occurs influence the way of the characters in the film in choosing the strategy of employing the utterances.

The fact that there is variation of ways and strategies in employing commissive utterances implies that one may use various ways and strategies in employing commissive utterances. It could give some variations in uttering commissive utterances. Those variations are influenced by the context of the conversation. The variation of ways and strategies in employing commissive utterances are uttered based on the context which is appropriate. In order to be able to use appropriate ways and strategies in employing commissive utterances, language learners, including EFL learners, need to have exposure to different phenomena of communication containing commissive utterances. Having the knowledge of those variation and strategies is very important for EFL learners to be able to use appropriate utterances in appropriate context. Therefore, EL instruction needs to provide students with material that can enrich their 
pragmatic awareness so that they can make use of the strategies in appropriate context.

According to the implication of the research, the writer wants to give some suggestions to EFL teacher and the students. First, EFL teacher should help the students to see the language in context, raise consciousness of the role of pragmatics, and explain the function

pragmatics plays in specific communicative events. In addition, EFL teacher should develop activities through which students use English in contexts (simulated and real) where they choose how they interact based on their understanding of the situation suggested by the activity. Then, EFL teacher should reinforce pragmatic knowledge through the common communicative events that take place daily in every EFL classroom. Moreover, EFL teacher can use video such as film, television program or other videos program as the teaching material or invite native speaking in classroom, in order to make the students experience and observe the role pragmatic in communication.

Second, the students, especially the English Department students, are expected to explore more about the various ways and strategies of people in employing speech acts, especially commissives.

\section{BIBLIOGRAPHY}

Adler, B. R. \& Rodman, G. (2006). Understanding

Human

Communication $\left(9^{\text {th }}\right.$ ed.). New York: Oxford University Press.

Allan, K. (1986). Linguistic Meaning. Volume Two. New York: Routledge \& Kegan Paul, Inc.

Holmes, J. (1992). An Introduction to

Sociolinguistics. London: Longman.
Searle, J. R. (1979). Expression and Meaning. New York: Cambridge University Press.

Tornbury,S. (2005). How to Teach Speaking. England: Pearson Education Limited.

Yule, G. (1996). Pragmatics. New York:

Oxford University Press.

